\title{
ISOLATION AND IDENTIFICATION OF TRICHODERMA SPECIES FROM SOILS FOR USING AGAINST SOME SOILBORNE FUNGAL PATHOGENS
}

\author{
Nada Kh. Abd El-Aziz ${ }^{\star}$, Abd El-Razek ${ }^{1}$, A.B. and Ibrahem ${ }^{1}$, S.A. \\ Genetics Dept., Fac. of Agric., Ain Shams Univ., P.O. Box 68, Hadyek Shoubra 11241, \\ Cairo, Egypt
}

*Corresponding author: nodi311@yahoo.com

Received 28 October, 2018,

Accepted 31 October, 2018

\begin{abstract}
Hydrolytic enzyme producing Trichoderma species have long been recognized as an agent for controlling plant diseases caused by various phytopathogenic fungi. A study was done to characterize four isolates of Trichoderma isolated from the rhizosphere of different crop plants to characterize and identify certain biocontrol related enzymes ( $\beta$ 1,3-glucanase and chitinase). Morphological and molecular characterize action of antagonistic ability of Trichoderma species were studied. On the basis of morphological and culture characteristics, the Trichoderma isolates were identified as $T$. harizanum (1 isolate), T. viride (3 isolates). These isolates were tested against plant pathogens (Rhizoctonia solani, Pythium and Fusarium oxysporum).

The best isolate producing chitinase (overproduction) was $T$. harizanum from (160 to 0.64) $\mathrm{mg} / \mathrm{ml}$. On the other hand the best isolate gave over production $\beta-1$; 3-glucanase over production was $T$. viride from (2250 to $2.20 \mathrm{mg} / \mathrm{ml})$
\end{abstract}

Keywords: Trichoderma species, Biocontrol, Antagonism, Chitinase, $\beta$-1,3-glucanase

\section{INTRODUCTION}

The filamentous fungus Trichoderma is one of the most potent agents for the biocontrol of plant pathogens (Cook and Vesth, 1991). Trichoderma is among the most exploited fungal biocontrol in agriculture for the management of plant diseases caused by wide spectrum of pathogens
(Mathivanan et al 2000). Production of extracellular proteolytic enzymes is one of the biocontrol mechanisms exerted by Trichoderma towards fungal pathogens. Several biocontrol agents alleviate the growth of pathogenic fungi by producing extracellular chitinase, which degrades the chitin polymers of fungal cell wall (Mathivanan et al 2000).

The antagonistic mechanism of Trichoderma spp. is due to inducing secretion of chitinolytic, proteolytic, and glycolytic enzymes and their controlling mechanism is still a hypothesis, in spite of numerous studies and reports. In time course of mycoparasitism, the cell wall-degrading enzymes act synergistically and exerted their action on pathogenic fungi. Thus, considerate the induction process of these enzymes is essential for selection of most significant Trichoderma spp. for biocontrol purpose.

Members of the fungal genus Trichoderma have been extensively studied, particularly due to their ability to secrete cellulose and chitinase degrading enzymes or to act as biocontrol agents . Most of the work has been carried out on strains of $T$. harizanum and T.viride. These strains have been extensively studied for their ability to produce extracellular $\beta-1,3$-glucanase and chitins enzymes, which act synergistically in the conversion of cellulose and chitin to glucose (Eveleigh, 1987).

The filamentous fungus Trichoderma is well known for its ability to secrete distinct enzymes, to degrade the cell wall of other filamentous fungi (Ridout et al 1985). This property is related to the finding that certain $T$. harizainum isolates are considered as bio fungicide candidates (Papavizas, 1985). One of the main problems in the applica- 
tion of this fungus as bio pesticide is that its chitinases and $\beta-1,3$-glucanase are inductive enzymes (Ulhoa and Peberdy, 1991) and consequently its fungicidal effect slowly develops. Because of the low efficiency, it seems necessary to breed this organism by mutagenesis (Sivan and Harman, 1991).

\section{MATERIALS AND METHODS}

\section{Isolation and identification of Trichoderma species}

A total four isolates of Trichoderma spp. Were isolated from rhizosphere soil of different cultivated crops such as Grape from silt loam soil and eggplant from loam soil samples by using potato dextrose agar (PDA) medium. PDA media were prepared and autoclaved at $121^{\circ} \mathrm{C}$ at $15 p s i$ for 20 mints. Penicillin at 100,000 unitsL- 1 and streptomycin at $0.2 \mathrm{~g}$ were added to sterilized stock media just before pouring to inhibit the bacterial growth. The media were poured in $9 \mathrm{~cm}$ diam. petri plates at $10 \mathrm{ml}$ per plate. Samples were inoculated over plates by multiple tube dilution technique (MTDT) and the plates were incubated at $26^{\circ} \mathrm{C}$ for $4-7$ days. Inoculated plate shows a mixture of multiple fungi and bacteria cultures. The desired fungal colonies were then picked and purified by streaking or by single spore and incubated at $26^{\circ} \mathrm{C}$ for 7 8 days. $1 \mathrm{ml}$ of distilled water was spread over the fully-grown culture of Trichoderma with a spade and then transferred to $99 \mathrm{ml}$ of distilled water to make a suspension. A drop from the diluted fungal suspension was taken over the slide and observe Trichoderma $s p$. Was observed under the microscope at 10-40X magnification.

\section{Pathogenicty}

The three pathogens used in this study were obtained Fusarium oxysporum, Rhizoctonia solani, and Pythium sp from the ACGEB. All strains were grown routinely on potato dextrose agar (PDA) at $25^{\circ} \mathrm{C}$ and $0.1 \%$ Triton $\mathrm{X}-100$ was included in some instances to reduce colony growth. Glucose minimal medium (GMM) (Cove 1966) was used as a defined medium and soil extract agar (SEA) was used to reproduce soil conditions.

Identifiable phenotypes on PDA medium of Trichoderma SPP.

( $T$. harzianum) formed 1-2 concentric rings with green conidial production, ( $T$. viride1) formed green conidia distributed throughout. An irregular yellow zone without conidia was present around the inoculum, ( $T$. viride 2) formed white pustules were also found growing on the green mat of conidia and ( $T$. viride 3 ) formed green conidia distributed throughout.

\section{Enzyme determination}

Enzyme source was prepared following the methods of (Dutta and Cheterjee, 2004). Sevendays old $T$. harzianum (both wild and mutant) cultured on PDA was used for inoculation of Czapek's Dox broth (basal medium). The later was supplemented with sucrose $(3 \% \mathrm{w} / \mathrm{v})$, fresh mycelial mat and dry mycelial mat as the soil carbon sources. The growth medium in the flasks was passed through filter paper (Whatman No. 1) after 10 days of incubation. Collected culture filtrates (enzyme source) were preserved in refrigerator at $4{ }^{\circ} \mathrm{C}$ with $0.02 \%$ (W/V) sodium azide. $\beta-1$, 3-Glucanase the dinitrosalicylic acid method of (Miller, 1959) was used to assay the $\beta-1$, 3-glucanase (laminarians) to study Chitins enzyme method of (Ohtakara, 1988) was followed to assay the enzymatic hydrolysis of colloidal chitin following the release of free $\mathrm{N}$-acetyl-glucosamine (NAGA) from colloidal chitin. Colloidal chitin was prepared as the method of Shimakara and Takiguchi (1988).

\section{Molecular characterization}

The total genomic DNA was extracted from each isolate of Trichoderma using the DNeasy mini spin columns kit (qiagen).

Inter-simple sequence repeats (ISSR) technique.

The DNA amplifications were performed in an automated thermal cycle (model Techno 512) programmed for one cycle at $94^{\circ} \mathrm{C}$ for 4 min followed by 45 cycles of $1 \mathrm{~min}$ at $94^{\circ} \mathrm{C}, 1 \mathrm{~min}$ at $45^{\circ} \mathrm{C}$, and $2 \mathrm{~min}$ at $72^{\circ} \mathrm{C}$. the reaction was finally stored at $72^{\circ} \mathrm{C}$ for $10 \mathrm{~min}$. Amplified products were fractioned according to size (using $1 \mathrm{Kbp}$ ladder marker) by electrophoresis in $1.5 \%$ agarose gels in TBE buffer at $120 \mathrm{~V}$ for $1 \mathrm{~h}$. The bands were visualized by ethidium bromide under UV florescence and photographed. 

soilborne fungal pathogens

Table 1. List of the ISSR-PCR primer and their nucleotide sequences used in the study.

\begin{tabular}{|c|c|c|}
\hline No. & Primer & sequence \\
\hline $\mathbf{1}$ & HB08 & 5 GTGTGTGTGTGTGG 3 \\
$\mathbf{2}$ & HB10 & 5` GAGAGAGAGAGACC 3` \\
$\mathbf{3}$ & HB12 & 5` CACCACCACGC 3` \\
$\mathbf{4}$ & HB13 & 5` GTGTGTGTGTGTCC 3’ \\
$\mathbf{5}$ & HB15 & 5` CACCACCACGC 3` \\
\hline
\end{tabular}

\section{RESULTS AND DISCUSSIONS}

\section{Isolations and identification of Trichoderma} spp.

The Trichoderma isolates were characterized by using distinctive morphological characters that includes rapid growth, green conidia, irregular yellow zone without conidia and white pustules.

A total of four isolates of Trichoderma spp. were isolated from rhizosphere soil of different cultivated crops such as Grape from silt loam soil and eggplant from loam soil samples by using potato dextrose agar (PDA) medium the Trichoderma isolates could be classified into two groups on the basis of culture and morphological characteristics descriped by Gams and Bissett (1998). These species of Trichoderma were identified as 4 isolates Trichoderma, 1 isolate ( $T$. harzianum) and 3 isolates ( $T$. viridl) Table (2).
Table 2. Isolates of Trichoderma spp. Used in the present study and their origin.

\begin{tabular}{|c|c|c|}
\hline $\begin{array}{c}\text { Isolate } \\
\text { code }\end{array}$ & $\begin{array}{c}\text { Source of } \\
\text { rhizosphere }\end{array}$ & species \\
\hline T1 & Grape & Trichoderma harzianum \\
T2 & Grape & $\begin{array}{c}\text { Trichoderma viridi } \\
\text { T3 }\end{array}$ \\
Egg plant & Trichoderma viridi \\
T4 & Egg plant & Trichoderma viridi \\
\hline
\end{tabular}

Culture characteristics comprising growth rate, color and colony appearance were examined and the difference in morphological characteristics of Trichoderma spp. are summarized in Table (3). These characteristics were regarded as taxonomically useful characteristics for Trichoderma (Samuels et al 2002). Colony appearance of the different species grown on PDA for 5 days at $28 \mathrm{C}$. on PDA Trichoderma harzianum formed 1-2 concentric rings with green conidial production (Table 3 ). On PDA Trichoderma viridi1 formed green conidia which distributed throughout the plate. An irregular yellow zone without conidia was present around the inoculum (Table 3). on PDA Trichoderma viridi2 formed white pustules which were also found to grow on the green mat of conidia (Table 3). On PDA Trichoderma viridi3 formed green conidia distributed throughout the plate (Table 3).

Table 3. morphological characteristics of Trichoderma spp. isolated from rhizosphere.

\begin{tabular}{|l|l|l|l|l|}
\hline Cod \# & \multicolumn{1}{|c|}{ Isolate } & identifiable phenotypes on PDA medium & $\begin{array}{l}\text { A Plant that has been } \\
\text { isolated from rizo- } \\
\text { sphere }\end{array}$ & Soil type \\
\hline 1 & $\begin{array}{l}\text { Trichoderma } \\
\text { harzianum } \\
\text { T. viride. } 1\end{array}$ & $\begin{array}{l}\text { formed 1-2 concentric rings with green co- } \\
\text { nidial production } \\
\text { green conidia distributed throughout. An } \\
\text { irregular yellow zone without conidia was } \\
\text { present around the inoculum } \\
\text { white pustules were also found growing on } \\
\text { the green mat of conidia } \\
\text { green conidia distributed throughout. }\end{array}$ & Grape & Egg plant \\
4 & $\begin{array}{l}\text { T. viride.2 } \\
\text { T. viride.3 }\end{array}$ & Egg plant & silt-loam \\
\hline
\end{tabular}

\section{Antagonistic activity}

The Trichoderma species were evaluated in vitro for their potential antagonizes the plant pathogenic fungi Rhizoctonia solani, Pythium $s p$ and Fusarium oxysporum the result of antagonism between Trichoderma and three pathogens, was shown in Table (4). Trichoderma species showed significant reduction in mycelia growth of fungal colonies of R.solani, Pythium and fusarium oxysporum as compared to the control. The Trichoderma harzianum and T.viridi 2 showed the highest inhibition. On the other hand, Trichoderma viride 2 and Trichoderma viridi 3 showed lowest inhibition. The data showed that the best antagonistic effect against three pathogens was obtained from Trichoderma harzianum. These results are in agreement with Mathew and Gupta (1998) who 
found that the mycelial growth of R.solani was strongly inhibited in vitro by the antagonist $T$. harizianum.

Trichoderma harzianum and $T$. viride were reported by several workers as the best antagonists against several soil and root borne plant pathogen (Poddar et al 2004). The potentiality of Trichoderma spp. as biocontrol agent of phytopathogenic fungi in several crops is well known especially to fusarium spp. and Rhizoctonia spp. (Poddar et al 2004 and Rogo et al 2007).

Table 4. Antagonistic effect of Trichoderma species isolates against growth of phytopathogens (Rhizoctonia solani, Pythium and Fusarium oxysporum) on PDA in vitro.

\begin{tabular}{|c|c|c|c|}
\hline \multirow[b]{2}{*}{ strain } & \multicolumn{3}{|c|}{$\%$ growth of pathogens } \\
\hline & $\begin{array}{c}\text { Rhizoctonia } \\
\text { solani }\end{array}$ & $\begin{array}{c}\text { Pythium } \\
s p\end{array}$ & $\begin{array}{l}\text { Fusarium } \\
\text { oxysporum }\end{array}$ \\
\hline T.harizinum & 78 & 75 & 75 \\
\hline T.viride1 & 92 & 89 & 85 \\
\hline T.viridi2 & 100 & 95 & 98 \\
\hline T.viridi3 & 98 & 95 & 100 \\
\hline
\end{tabular}

Screening of the isolated Trichoderma spp. for enzyme activity

\section{1- Production and assay of chitins and activity}

The results present in Table (5) showed that all the four Trichoderma isolates were able to grow and produce chitins enzyme in the presence of chitin as the sole carbon source. The results indicates that Trichoderma isolates T1 and T2 exhibit highest activities of chitinase (Table 5) where the maximum amount of chitinase (from160 to 0.64 $\mathrm{mg} / \mathrm{ml}$ ) was ex/ml) was exerted by $\mathrm{T} 1$ isolate. On the other hand, the minimum amount of chitinase (from 142 to $0.64 \mathrm{mg} / \mathrm{ml}$ ) was exerted by T4.chitinase produced Chitinase produced by some Trichoderma species which is the key enzyme in the lysis of cell walls during mycoparasite action against phytopathogenic fungi.

Table 5. Assay of chitinase specific activity in Trichoderma culture filtrate.

\begin{tabular}{|l|l|}
\hline Code & Chitinase activity $(\mathrm{mg} / \mathrm{ml})($ mean \pm S.E $)$ \\
\hline & Chitinase \\
T1 & $160 \pm 0.64$ \\
T2 & $142 \pm 0.64$ \\
T3 & $125 \pm 0.54$ \\
T4 & $121 \pm 0.80$ \\
\hline
\end{tabular}

These enzymes may be important in the destruction of plant pathogens and could be used as the basis of screening for potential biocontrol agents (DE La cruz et al 1992). El-Katatny et al (2000) showed that T.harzianum Rifai (T24) was the most suitable isolates for the production of chitinase enzyme among 24 tested isolates.

\section{Production and assay of cellulase and activity.}

Results presented in Table (6) indicated that the maximum amount of $\beta, 1-3$ Glucanse ranged from 2250 to $2.20 \mathrm{mg} / \mathrm{ml}$ by T2 isolate. On the other hand, the minimum amount of $\beta, 1-3$ Glucanse from 1252 to 1.04 by T4 isolate. The role of $\beta-1,3-$ glucanase in preventing fungal disease has been well studied, for example, glucanases have been shown to serve as bio-control agents in agricultural applications by protecting plants from fungal invasion. Bacteria secreted glucanase and other fungal cell wall-degrading enzymes are commonly considered as potential biocontrol agents against plant-pathogenic fungi .Therefore, degrading enzymes of the bacteria that produce these enzymes could be used as biological control agents. Many chitinolytic and glucanolytic microorganisms have potential for controlling fungal plant pathogens.

Table 6. Assay of $\beta-1,3$-glucanase specific activity in Trichoderma culture filter.

\begin{tabular}{|c|l|}
\hline code & $\beta-1,3$-glucanase activity $(\mathrm{mg} / \mathrm{ml})$ (mean \pm \\
& S.E) \\
\hline & B, $1-3$ Glucanse \\
T1 & $2160 \pm 2.99$ \\
T2 & $2250 \pm 2.20$ \\
T3 & $1365 \pm 1.15$ \\
T4 & $1252 \pm 1.04$ \\
\hline
\end{tabular}

\section{ISSR analysis}

A total of five ISSR primers were used to screen four Trichoderma spp. genotypes (Table 6). A total of 58 bands were amplified among the four Trichoderma species genotypes, 21 were monomorphic, 6 species specific bands, and 23 were polymorphic distinct bands. The results showed that primers $\mathrm{HB} 08$ and HB15 were highly polymorphic ( $66 \%$ and $88 \%$ polymorphism) and produced wide molecular band length (151 to 1079 bp) and (149 to $1224 \mathrm{bp}$ ) respectively. Moreover, primer HB12 showed the least polymorphism (25\%) and produced molecular band length that ranged from (333 to 1302). HB08, HB13 and HB15 

soilborne fungal pathogens

gave the highest species- specific bands and HB10 and HB12 gave the least specific bands. Source of polymorphism in ISSR assay may be due to deletion, addition or substitution of base within the priming site sequence. High diversity is the reflection of adaptation to environment, which is beneficial to its propagation, conservation, the domestication of wild species, and the screen of specific locus (Fig. 1).
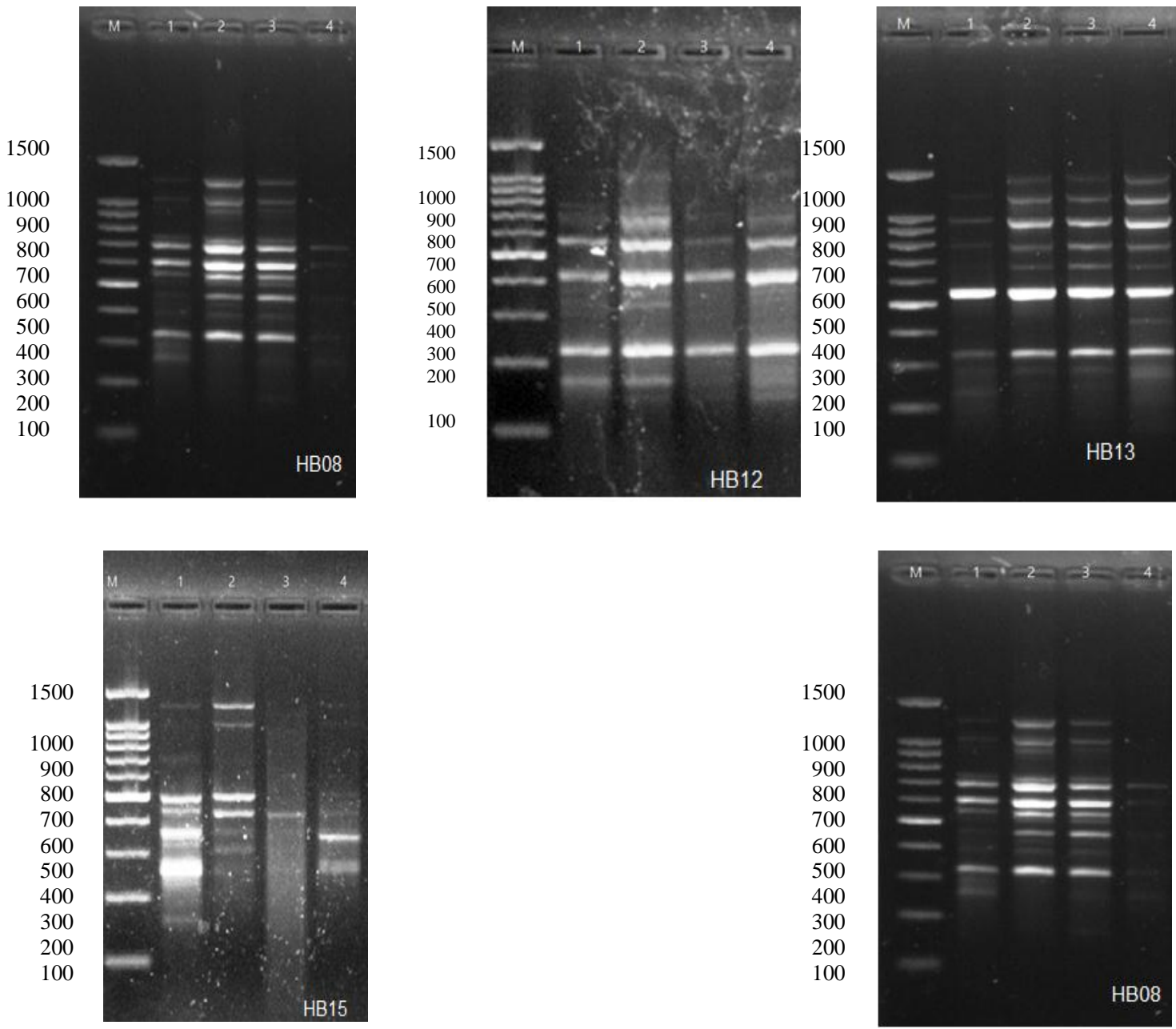

Fig. 1. PCR products with ISSR marks profiles, HB08, HB10, HB12, HB13, HB15and ISSR primers among the four Trichoderma spp. genotypes under different habitats. $(\mathrm{M})=\operatorname{Marker}, 1=(T$. harizinum $), 2=$ ( $T$. viride 1$), 3=(T$. viridi 2$), 4=(T$. viride 3$)$.

Table 7. HB08, HB10, HB12, HB13, HB15, ISSR primers among the four Trichoderma spp. genotypes under different habitats. $(\mathrm{M})=$ Marker, $1=(T$. harizinum $), 2=(T$. viride1 $), 3=(T$. viridi2 $), 4=(T$.viride3 $)$.

\begin{tabular}{|c|c|c|c|c|c|c|c|}
\hline $\begin{array}{c}\text { Polymorphism } \\
\text { percentages }\end{array}$ & $\begin{array}{c}\text { Total } \\
\text { amplified } \\
\text { bands }\end{array}$ & $\begin{array}{c}\text { Unique } \\
\text { bands }\end{array}$ & $\begin{array}{c}\text { Polymorphic } \\
\text { Bands }\end{array}$ & $\begin{array}{c}\text { Monomorphic } \\
\text { bands }\end{array}$ & $\begin{array}{c}\text { Length } \\
\text { Range(pb) }\end{array}$ & $\begin{array}{c}\text { Primer } \\
\text { sequence }\end{array}$ & $\begin{array}{c}\text { Primer } \\
\text { code }\end{array}$ \\
\hline $66 \%$ & 12 & 2 & 6 & 4 & $151-1079$ & 5 GTGTGTGTGTGTGG 3` & HB08 \\
$54 \%$ & 11 & 0 & 6 & 5 & $222-1241$ & 5 GAGAGAGAGAGACC 3` & HB10 \\
$25 \%$ & 8 & 0 & 2 & 6 & $333-1302$ & 5 CACCACCACGC 3` & HB12 \\
$50 \%$ & 10 & 2 & 3 & 5 & 140-1084 & 5 GTGTGTGTGTGTCC 3` & HB13 \\
$88 \%$ & 9 & 2 & 6 & 1 & 149-1224 & 5 CACCACCACGC 3` & HB15 \\
\hline
\end{tabular}



$14^{\text {th }}$ Conf. Agric. Develop. Res., Fac. of Agric., Ain Shams

Univ., March, 2019., Cairo, Egypt

Special Issue, 27(1), 545 - 552, 2019

Website: http://strategy-plan.asu.edu.eg/AUJASCI/

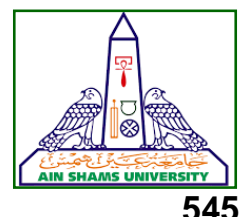

Dendrogram analysis

Similarity matrix was developed by SPSS computer package system, the closest relationship was scored between T. viridi 2 (T3) and T. viridi 4 (T4), while the least relationship scored between $T$. virdie 3 (T2) and $T$. viride 1 (T2).

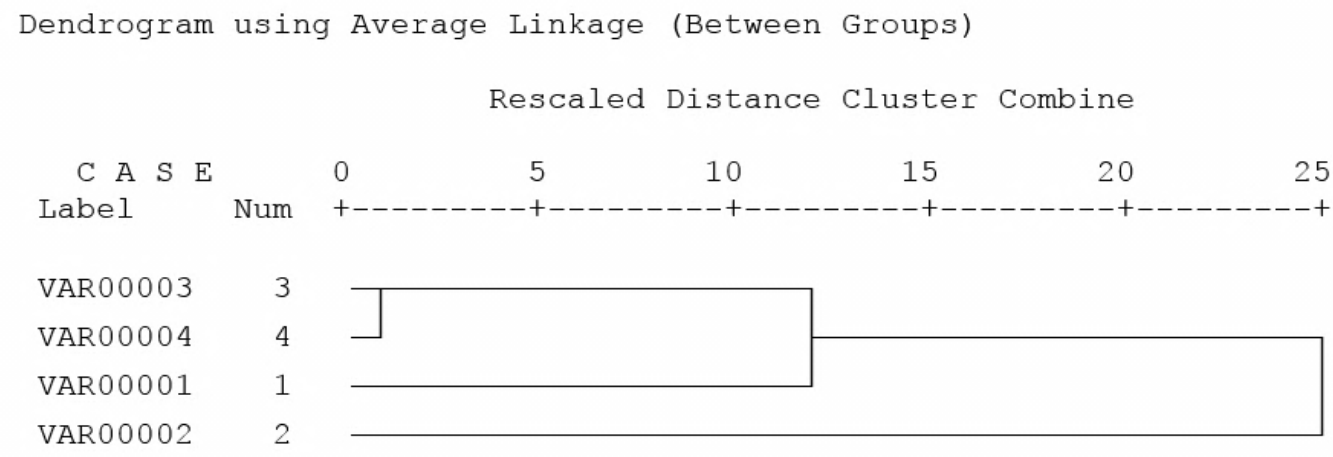

Proximity Matrix

\begin{tabular}{|c|c|c|c|c|}
\hline \multirow{2}{*}{ Case } & \multicolumn{4}{|c|}{ Matrix File Input } \\
\cline { 2 - 5 } & VAR00001 & VAR00002 & VAR00003 & VAR00004 \\
\hline VAR00001 & .000 & 12.000 & 9.000 & 12.000 \\
VAR00002 & 12.000 & .000 & 9.000 & 16.000 \\
VAR00003 & 9.000 & 9.000 & .000 & 9.000 \\
VAR00004 & 12.000 & 16.000 & 9.000 & .000 \\
\hline
\end{tabular}

Dendrogram using Average Linkage (Between Groups)

Rescaled Distance Cluster Combine

$\begin{array}{lllllll}\text { C A S E } & 0 & 5 & 10 & 15 & 20 & 25\end{array}$

Label Num

\section{CONCLUSION}

Trichoderma strains are known to produce extracellular lytic enzymes, including chitinase, cellulase, and protease which have a wide range of application in biological controlled, agriculture and other industries. Because of the important of these products, these present studies aimed to isolate and identification Trichoderma spp. to genetically improve extracellular lytic enzyme as chitinase and $\beta-1,3$-glucanase to use against plant pathogens such as Rhizoctonia solani, Pythium sp and Fusarium oxysporum.

\section{REFERENCES}

Cove, D.J.1966. The induction and resin of nitrate reductase in the fungus Aspergillus nodulins. Biochim biophys Acta., 113, 51-56.

De la cruze, J., Hidalgo-Gallego, A., lora, J. M., Benitez, T., Pintor-Toro, J. A. and Liobell, A.1992. Isolation and characterization of three chitins from Trichoderma harizinum. Eur $\mathbf{J}$ Biochem, 206, 859-867.

Dutta S. and Chatterjee N.C., 2004. Raising of carbendazim-tolerant mutants of Trichoderma and variations in their hydrolytic enzyme activity in relation to mycoparasitic action against Rhizopus stolonifer. Journal of Plant Diseases and Protection, 111(6), 557-565.

El- Katatny, M.H., Somitsch, W., Robra, K.H., ElKatatny, M.S. and Gubitz, G. M. 2000. Production of chitins and B1-3- glucanase by $T$. 

soilborne fungal pathogens

harizinum, Food Technol. Biotecnol., 38(3), 173- 180.

Eveleigh, D.E., 1987. Cellulase: A perspective philosophical transactions of the royal society of London, Series B-Biological Sciences, 321, 435-447.

Gams, W. and Bissett, J. 1998. Morphology and Identification of Trichoderma. Trichoderma and Gliocladium. Basic Biology, Taxonomy and genetics, In: Kubicek CP. and Harman G.E.(eds.), pp. 3-34. Taylor \& Francis Ltd,

Mathew, K.A. and Gupta, S.K. 1998. Biological control of root rot of French bean caused by Rhizoctoni solani. Journal of Mycology and Plant Pathology, 28 (2), 202- 205.

Mathivanan, N., Srinivasan, K. and Chelliah, S. 2000. Biological control of soil-borne diseases of cotton, eggplant, okra and sunflower by Trichoderma viride. J. Plant Dis. and Protec., 107, 235-244.

Miller, G.L. 1959. Use of dinitrosalicylic acid reagent for determination of reducing sugar. Analytical Chemistry. 31, 426-429.

Ohtakara A. 1988. Chitins and $\beta-\mathrm{N}$-acetylhexosaminidase from Pycnoporus cinnabarainus. Meth. Enzymol.168, 467-468.

Papavizas, G.C. 1985. Trichoderma and Gliocladium: biology, ecology and potential for Biocontrol. Annu. Rev. Phytopathol., 23, 43- 54.

Poddar, R.P., Gupta, S.R., Sarma, Y.R. and Jackson, G.V.H. 2004. Diseases of ginger and their control with Trichoderma harizinum. Indian Phytopathol., 55, 173- 177.
Ridout, C.J., Coley-Smith, I.R. and Lynch, J.M. 1986. Enzyme activity and electrophoretic profile of extra cellular protein induced in Trichoderma spp. by cell walls of Rhizoctonia solani J. Gen. Microbiol., 132, 2345-2352.

Rogo, F.G. Reynoso, M.M., Sofia, M.F., Chulzel, N. and Torres A.M. 2007. Biological control by Trichoderma species of fusarium solani causing peanut brown root rot under field condition. Crop Protection, 26, 549- 555.

Samuels, G.J., Dodd, S.L., Gams, W., Castlebury, L.A. and Petrini, O. 2002. Trichoderma species associated with the green mold epidemic of commercially grown Agaricus bisporus. Mycologia, 94, 146- 170.

Shimakara K. and Takiguchi Y. 1988. Preparation of crustacean chitin. Meth. Enzymol.161, 126-132.

Sivan, A. and Harman G.E. 1991. Degradation of fungal cell walls by lytic enezymes of Trichoderma harzinum. Journal of General Microbiology, 135, 675-682.

Ulhoa, C.J. and Peberdy J.F. 1991. Regulation of chitinase synthesis in Trichoderma harizanum. J. Gen. Microbial. 137, 216-332. 
عزل وتعريف انواع التريكوديرما من التربه لاستخدامها ضد بعض المسبيات الفطريه

\section{التي تنتقل عن طريق التربه}

ندي خالد عبد العزيز1"- أثرف بكري عبد الرازق 1- سمير عبد العزيز ابراهيم1

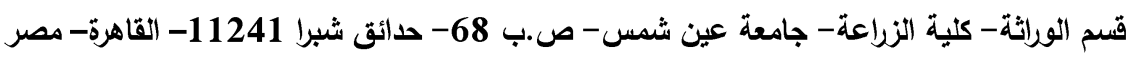

"Corresponding author: nodi311@yahoo.com

Received 28 October, 2018, Accepted 31 October, 2018

Rhizoctonia solani, Pythium and Fusarium oxysporum السلالات T1, T2 هي السلالات الاكفأ في التضاد Rhizoctonia solani, Pythium and لفطريات Fusarium oxysporum

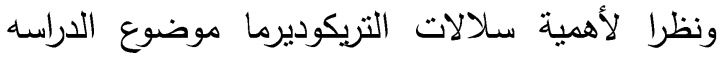

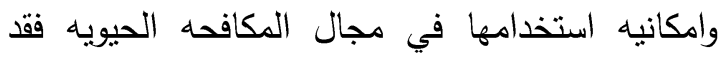

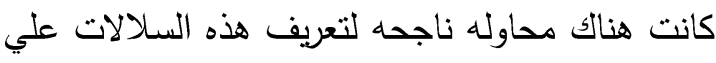
المستوي الييوكيماوي والجزيئي باستخدام تقنيف تانيه تفاعل البلمره المتسلسل باستخدام خمسه من البادئات - ISSR

.PCR

الكلمات الدالة: أنواع التريكوديرما، المكافحة الحيوية، ISSR-PCR مضاد الفطريات، شيتنينيز ، بادئات التردير، النات

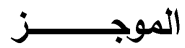

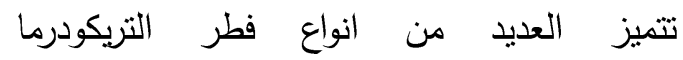
Trichoderma علي انتاج مركبات تهم الانسان ذات قيمه اقتصاديه يمكن إستخدامها في المجالات الصناعيه والبيئيه

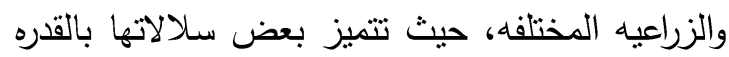

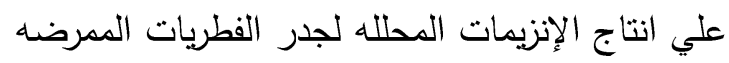

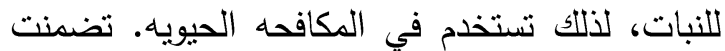
الدراسه عزل أربع عزلات محليه جمعت من منطقتين

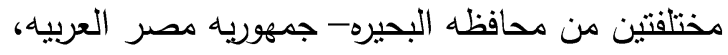

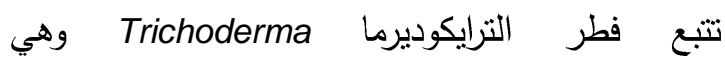
T. viridig harizinum T. Trichoderma sp إجراء تجربه التضاد (antagonism) بين فطر الـ و Trichoderma 